\title{
Enhancement of Biometrics, Anatomical Characteristics and Fatty Acids Profile of Sunflower Plants by Foliar Application with Yeast Extract and Salicylic Acid
}

\begin{abstract}
Engy A. Seleem and Z. K. Taha
Department of Agricultural Botany, Faculty of Agriculture, Cairo University, Giza, Egypt. Received: 30 Sept. 2019 / Accepted 20 Nov. 2019 / Publication date: 05 Dec. 2019

ABSTRACT

Field experiments were carried out during the two successive summer seasons; 2017 and 2018, at the Agricultural Experiments and Researches Station, Faculty of Agriculture, Cairo University, Giza, Egypt to study the effect of foliar spray with yeast extract at 2, 4, 8 and $12 \mathrm{~g} / \mathrm{L}$ concentrations and salicylic acid (SA) at 50, 100, 150 and $300 \mathrm{mg} \mathrm{L}^{-1}$ on morphological, anatomical and yield characters as well as on fatty acids analysis of sunflower cultivar Sakha-53. Results indicated that the first three concentrations of yeast extract as well as salicylic acids improved all the studied growth parameters (plant height $(\mathrm{cm})$, number of internodes, leaf number/plant, stem diameter $(\mathrm{cm})$, shoot fresh and dry weights/plant $(\mathrm{g})$, as well as yield characters (Head diameter $(\mathrm{cm})$, number of seeds/capitulum, seed yield/ plant (g), seed index (100 seed weight $(\mathrm{g}))$, while $12 \mathrm{~g} / \mathrm{L}$ yeast extract concentration and 300 $\mathrm{mg} \mathrm{L}^{-1} \mathrm{SA}$ decreased the previous growth and yield parameters. The best results of these parameters were obtained at $4 \mathrm{~g} / \mathrm{L}$ yeast extract concentration or $100 \mathrm{mg} \mathrm{L}^{-1} \mathrm{SA}$, which gave also a positive effect on the anatomical structure, as the whole stem diameter was enlarged as a result of foliar spray with these concentrations of yeast or SA; this increment in stem diameter reflects the increase in the internal tissues i.e., fiber cap, phloem, xylem, and pith diameter. Contrary, cortex layer thickness decreased to less than the control plants. These two concentrations also improved the oil quality and content by increasing the unsaturated fatty acids (oleic, linoleic and linolenic) and decreasing the saturated fatty acids (palmitic and stearic).
\end{abstract}

Keywords: Sunflower, Yeast extract, Salicylic acid, Morphology, Anatomy, Yield, Fatty acid analysis.

\section{Introduction}

Sunflower (Helianthus annuus L.) is considered one of the most important oilseed crops, ranking $4^{\text {th }}$ after soybean, canola, peanut oil (FAS-USDA, 2017). The total world production of sunflower is 45 million tonnes with cultivated areas 26 million hectares. In 2016, the average yield of sunflower was 1.78 metric tons per ha. The Major producing countries of sunflower seeds around the world are Ukraine, Russia, European Union and Argentina (Konyal 12017). Egypt is one of the major sunflower oil importing countries, with cultivated area not exceeding 6000 ha. The total seed production was 20.000 tonnes in 2017 with an average yield of 3.33 tonnes /ha (FAOSTAT 2019). Sunflower oil is rich with unsaturated fatty acids (oleic, linoleic and linolenic) with lower content of saturated fatty acids (palmitic and stearic), it is also rich with natural antioxidants, so it can be added to many food as a healthy oil (Hamed et al., 2012 and El Mantawy, 2017). Seeds of sunflower contain high percentage of oil reaching $45 \%$, each $100 \mathrm{~g}$ of seeds contain $20.78 \mathrm{~g}$ protein, total lipid (fat) up to $51.46 \mathrm{~g}$, ash up to $3.02 \mathrm{~g}$, and fiber up to $8.6 \mathrm{~g}$. (USDA, 2008; Hamza and Safina, 2015 and El Mantawy, 2017).

Recently, there is a global trend towards the use of natural substances which are safe and nonpollutant to the environment. Yeast extract is a rich source of phytohormones; auxin, cytokinins, vitamins, enzymes, amino acids and minerals. Consequently, it plays an important role in cell division and enlargement, protein and nucleic acids synthesis and chlorophyll formation leading to the improvement of plant growth (Abou EL-Yazied and Mady, 2012; Dawood et al., 2013 and Marzauk et al., 2014). It is also a natural source of amino acids, peptides and the best source of B-complex vitamins such as B1, B2, B6 and B12, carbohydrates, sugars, and minerals (El-Desuki and E1Gereadly 2006 and Wanas, 2006). It was reported by Abdallah et al. (2016) that foliar application of yeast extract increased shoot length, fruiting branches number/plant, shoot weight/plant and seed

Corresponding Author: Engy A. Seleem, Department of Agricultural Botany, Faculty of Agriculture, Cairo University, Giza, Egypt. E-mail: engy.seleem@agr.cu.edu.eg 
weight/plant of quinoa plants. Nofal et al. (2016) found that using yeast extract enhanced growth and flowering characters of Calendula plant.

Salicylic acid (SA) is an important plant phytohormone, it is considered as a signaling molecule that involved in the regulation of physiological processes in plants i.e. photosynthesis, transpiration ((Jayakannan et al., 2013; Youssef et al., 2017 and Shaki et al., 2019). Exogenous application of SA increases plant tolerance against pathogens, insects, pests and abiotic stresses by changing the activities of antioxidant enzymes and decreasing generation of ROS (Abdul Qados, 2015). SA is also involved directly in plant growth, flowering and ion uptake, it affects stomatal movement and enhance the levels of plant pigments (Abdel-Hakim et al., 2012). The former studies on the important role of SA on plant growth were reported by Abdel-Hakim et al. (2012) on Snap Bean; Orabi et al. (2013) on faba bean; Abdul Qados (2015) on Pepper plant and Seleem (2016) on Calendula plant.

The objective of this investigation is to enhance the morphological and yield characters as well as chemical properties of seed oil fatty acids content of sunflower (Helianthus annuus L.) plant by foliar application of natural substances; yeast extract and Salicylic acid.

\section{Materials and Methods}

Field trials were conducted during the two growing seasons; 2017 and 2018 at the Agricultural Experiments and Research Station, Faculty of Agriculture, Cairo University, Giza, Egypt to determine the effect of foliar application of yeast extract and salicylic acid on morphological, anatomical, seed yield plant characters and seed fatty acids content of sunflower plants. Seeds of sunflower (Helianthus annuи L.) cultivar Sakha-53 were obtained from Field Crops Research Institute, Agricultural Research Center, Giza, Egypt. Seeds were sown on $9^{\text {th }}$ April 2017 in the first season and replicated on $12^{\text {th }}$ April 2018 in the second one in Randomized Complete Block Design with three replicates, each replicate divided into 9 plots, each plot contain 4 rows, $60 \mathrm{~cm}$ apart and $50 \mathrm{~cm}$ distance between plants. Plants were sprayed twice; the first at six weeks from sowing date and the second was after two weeks from the first one. The treatments were as follows: control plants sprayed with tap water, yeast extract at 2, 4, 6 and $10 \mathrm{~g} / \mathrm{L}$ concentrations and salicylic acid at 50, 100, 150 and $300 \mathrm{mg} \mathrm{L}^{-1}$ concentrations.

\section{Recording data}

\section{Morphological characters}

In both seasons, a random sample of 15 plants per treatment ( 5 plants per replicate) was assigned at flowering stage (75 day from sowing) to study the morphological parameters; plant height $(\mathrm{cm})$, number of internodes, leaf number/plant, stem diameter $(\mathrm{cm})$, shoot fresh weight/plant $(\mathrm{g})$, shoot dry weight/plant (g).

\section{Yield parameters}

Head diameter $(\mathrm{cm})$, number of seeds/capitulum, seed yield/plant $(\mathrm{g})$, seed index (100 seed weight $(\mathrm{g})$ were measured after 120 day from sowing date.

\section{Anatomical studies}

Plant specimens from middle internode of main stem were taken from control plants and those treated with yeast extract and salicylic acid at the age of 75 days from sowing date. These plant specimens were prepared for the anatomical study according to Nassar and El-Sahhar, (1998). Measurements of histological aspects were expressed in microns $(\mu)$.

\section{Fatty acids analysis}

Extractions and separation of fatty acids were prepared according to A.O.A.C. (2000) and Vogel (1975), respectively. While the determination of fatty acids by GLC described by farag et al. (1981).

\section{Statistical analysis}

Mean data were statistically analyzed according to Snedecor and Cochran (1982), using MSTAT - C software. 


\section{Results and Discussion}

\section{Vegetative characteristics}

Data dealt with plant height, number of internodes/plant, number of leaves/plant, stem diameter $(\mathrm{cm})$, shoot fresh and dry weights $(\mathrm{g})$ are presented in Table (1).

Regarding the effect of yeast extract foliar application, results showed that the $2 \mathrm{~g} / \mathrm{L}$ yeast extract concentration caused non-significant enhancement for all growth parameters, while 4 and $8 \mathrm{~g} / \mathrm{L}$ enhanced significantly all the previous characters in both seasons. The best results were obtained at 4 $\mathrm{g} / \mathrm{L}$ concentration which enhanced the former characters by $34.2,17.9,30.4,33.4,30.2$ and $28.1 \%$ in the first season and by $30.1,14.4,28.2,30.5,28.5$ and $25.1 \%$ in the second season, respectively. On the other hand, the highest concentration of yeast extract $12 \mathrm{~g} / \mathrm{L}$ caused non-significant reduction in plant height and number of internodes, while, number of leaves/plant, stem diameter $(\mathrm{cm})$, shoot fresh weight $(\mathrm{g})$ and shoot dry weight were significantly decreased in both seasons.

Table 1: Effects of different concentrations of yeast extract and salicylic acid on vegetative characteristics of sunflower plant (at 75 days after sowing) in 2017 and 2018.

\begin{tabular}{|c|c|c|c|c|c|c|}
\hline \multicolumn{7}{|c|}{ Vegetative growth characters } \\
\hline \multicolumn{7}{|c|}{$1^{\text {st }}$ Season } \\
\hline & $\begin{array}{l}\text { Plant height } \\
\text { (cm) }\end{array}$ & $\begin{array}{l}\text { No. of } \\
\text { Internode } \\
\text { /plant }\end{array}$ & $\begin{array}{c}\text { No. of } \\
\text { Leaves } \\
\text { /plant }\end{array}$ & $\begin{array}{c}\text { Stem } \\
\text { Diameter } \\
(\mathbf{c m})\end{array}$ & $\begin{array}{c}\text { Shoot } \\
\text { fresh } \\
\text { Weight } \\
\text { /plant } \\
\text { (g) }\end{array}$ & $\begin{array}{c}\text { Shoot } \\
\text { Dry } \\
\text { Weight } \\
\text { /plant } \\
\text { (g) }\end{array}$ \\
\hline Control & 137.53 & 29.77 & 31.22 & 2.03 & 585.59 & 149.71 \\
\hline Yeast extract $2 \mathrm{~g} / \mathrm{L}$ & 150.70 & 31.00 & 33.43 & 2.16 & 634.59 & 169.28 \\
\hline Yeast extract $4 \mathrm{~g} / \mathrm{L}$ & 184.69 & 35.10 & 40.74 & 2.71 & 762.62 & 191.83 \\
\hline Yeast extract $8 \mathrm{~g} / \mathrm{L}$ & 158.09 & 32.28 & 36.31 & 2.52 & 693.48 & 182.58 \\
\hline Yeast extract $12 \mathrm{~g} / \mathrm{L}$ & 129.46 & 27.32 & 28.25 & 1.80 & 518.66 & 103.03 \\
\hline Salicylic acid $50 \mathrm{mg} \mathrm{L}^{-1}$ & 142.51 & 32.10 & 33.13 & 2.21 & 590.6 & 158.12 \\
\hline Salicylic acid $100 \mathrm{mg} \mathrm{L}^{-1}$ & 175.77 & 34.79 & 38.13 & 2.51 & 723.33 & 183.46 \\
\hline Salicylic acid $150 \mathrm{mg} \mathrm{L}^{-1}$ & 168.75 & 32.72 & 35.52 & 2.30 & 676.19 & 178.32 \\
\hline Salicylic acid $300 \mathrm{mg} \mathrm{L}^{-1}$ & 125.30 & 27.30 & 27.82 & 1.78 & 497.9 & 98.48 \\
\hline L.S.D(0.05) & 15.56 & 2.5 & 2.61 & 0.22 & 56.85 & 27.53 \\
\hline \multicolumn{7}{|c|}{$2^{\text {nd }}$ Season } \\
\hline & $\begin{array}{l}\text { Plant height } \\
\text { (cm) }\end{array}$ & $\begin{array}{l}\text { No. of } \\
\text { Internode } \\
\text { /plant }\end{array}$ & $\begin{array}{c}\text { No. of } \\
\text { Leaves } \\
\text { /plant }\end{array}$ & $\begin{array}{c}\text { Stem } \\
\text { Diameter } \\
(\mathrm{cm})\end{array}$ & $\begin{array}{c}\text { Shoot } \\
\text { fresh } \\
\text { Weight } \\
\text { /plant } \\
\text { (g) }\end{array}$ & $\begin{array}{c}\text { Shoot } \\
\text { Dry } \\
\text { Weight } \\
\text { /plant } \\
\text { (g) }\end{array}$ \\
\hline Control & 130.84 & 28.33 & 29.71 & 2.00 & 490.9 & 123.81 \\
\hline Yeast extract $2 \mathrm{~g} / \mathrm{L}$ & 140.29 & 29.66 & 31.25 & 2.21 & 511.39 & 135.02 \\
\hline Yeast extract 4g/L & 170.30 & 32.41 & 38.11 & 2.61 & 631.06 & 155.00 \\
\hline Yeast extract $8 \mathrm{~g} / \mathrm{L}$ & 147.65 & 30.37 & 32.25 & 2.35 & 567.95 & 143.42 \\
\hline Yeast extract $12 \mathrm{~g} / \mathrm{L}$ & 119.61 & 28.21 & 27.61 & 1.72 & 418.25 & 101.53 \\
\hline Salicylic acid $50 \mathrm{mg} \mathrm{L}^{-1}$ & 136.94 & 28.87 & 31.62 & 2.03 & 505.14 & 129.97 \\
\hline Salicylic acid $100 \mathrm{mg} \mathrm{L}^{-1}$ & 163.77 & 32.12 & 35.81 & 2.42 & 588.76 & 151.23 \\
\hline Salicylic acid $150 \mathrm{mg} \mathrm{L}^{-1}$ & 146.47 & 29.54 & 33.17 & 2.25 & 548.52 & 139.97 \\
\hline Salicylic acid $300 \mathrm{mg} \mathrm{L}^{-1}$ & 116.78 & 28.00 & 27.57 & 1.61 & 387.53 & 96.13 \\
\hline L.S.D(0.05) & 14.31 & 1.7 & 2.00 & 0.23 & 40.63 & 15.91 \\
\hline
\end{tabular}

Quite similar results were reported by Abou EL-Yazied and Mady (2012) who found that 5ml/1 yeast extract stimulated number of leaves/plant, dry weights of both stems and leaves per plant, total leaf area of broad bean plant. Abdallah et al. (2016) stated that spraying quinoa plants with yeast extract at 5,10 and $15 \mathrm{~g} / \mathrm{L}$ concentrations, increased shoot length, fruiting branches number/plant, shoot weight/plant and seed weight/plant. Dawood et al. (2019) stated that foliar application of yeast extract at $75 \mathrm{~L} /$ fed increased fresh and dry weight of both shoot and root/plant, capsules yield/plant, straw and seed yield/fed of Flax plant. The increment in plant growth as a result of yeast extract may 
be attributed to the high percentage of plant hormones (auxin and cytokinin), vitamins, especially vitamin $\mathrm{B}$, amino acids, and protein stimulating cell division and enlargement as well as the synthesis of proteins, nucleic acids and chlorophyll (El-Toham et al., 2008 and Shalaby and El-Ramady, 2014).

Concerning the effect of salicylic acid on sunflower growth characters, data in Table (1) revealed that SA at 50,100 and $150 \mathrm{mg} \mathrm{L}^{-1}$ concentrations increased all growth parameters. This increment was insignificant with $50 \mathrm{mg} \mathrm{L}^{-1}$ concentration while the other two concentrations increased significantly all the growth parameters in the two growing seasons except the number of internodes with $150 \mathrm{mg} \mathrm{L}^{-1}$ concentration in the second season which increased insignificantly. The most effective concentration was $100 \mathrm{mg} \mathrm{L}^{-1}$ which gave the highest values of all characters, these values, in both seasons, were 27.8 and $25.1 \%$ for plant height; 16.8 and $13.3 \%$ for number of internode/plant; 22.1 and 20.5 for number of leaves/plant; 23.6 and $21.0 \%$ for stem diameter; 23.5 and $19.9 \%$ for shoot fresh weight; 22.5 and $22.1 \%$ for shoot dry weight. The lowest values were obtained by treatment with $300 \mathrm{mg} \mathrm{L}^{-1} \mathrm{SA}$ concentration, which decreased plant height and number of internodes insignificantly, while the rest of characters were decreased significantly in the first and second seasons.

These results are in agreement with Khandaker et al. (2011) who recommended the application of SA $10^{-5} \mathrm{M}$ concentration in order to improve growth and yield characters of red amaranth plant. Hayat et al. (2012) stated that spraying chickpea plant with $10^{-5} \mathrm{~mol} / \mathrm{L}$ of SA increased dry mass per plant. Abdel-Hakim et al. (2012) found that application of SA at $1.0 \mathrm{mM}$ concentration enhanced growth characters, while using $2.0 \mathrm{mM}$ concentration gave shortest plants and decreased plant fresh and dry weights of Snap Bean plants. Results obtained by Soltani et al. (2014) showed that application of SA $100 \mathrm{ppm}$ concentration was better than $50 \mathrm{ppm}$ in enhancing fresh and dry weights of calendula plants. Seleem (2016) stated that application of SA at $200 \mathrm{ppm}$ increased significantly all growth and yield characters of calendula plant, while $400 \mathrm{ppm}$ concentration caused a significant reduction in all characters. Noreen et al. (2017) found that the shoot fresh and dry weights of sunflower were increased significantly by the foliar application of salicylic acid at $200 \mathrm{mg} \mathrm{L}^{-1}$.

As the plant hormone involved in number of plant processes, Salicylic acid is an endogenous plant hormone. SA contributes in different plant metabolism (Abdel-Hakim et al., 2012). It's important for growth and development, enhancing flowering initiation, contributing in plant defense system by reducing the production of ROS (Hasanuzzaman et al., 2015 and Noreen et al., 2017). Moreover, SA plays a vital role in enhancing the photosynthetic capacity and stomatal conductance (Noreen and Ashraf 2008 and Noreen et al., 2017).

\section{Yield characteristics}

Head diameter, number of seeds/capitulum, seed yield/plant (g) and 100 seed weight $(\mathrm{g})$ were increased by foliar application of yeast extract 2,4 and $8 \mathrm{~g} / \mathrm{L}$ or salicylic acid at 50,100 and $150 \mathrm{mg}$ $\mathrm{L}^{-1}$ concentrations at 120 days after sowing during the two growing seasons as shown in Table (2). The lowest concentration of either yeast or SA gave insignificant enhancement, while the other two concentrations showed significant increment at all yield characters in both seasons. The maximum enhancement effect was induced in plants sprayed with $4 \mathrm{~g} / \mathrm{L}$ yeast extract and $100 \mathrm{mg} \mathrm{L}^{-1} \mathrm{SA}$ during the two growing seasons. The highest concentration; $12 \mathrm{~g} / \mathrm{L}$ yeast extract and $300 \mathrm{mg} \mathrm{L}^{-1} \mathrm{SA}$, reduced all the previous yield parameters insignificantly in the first season, while the second season was significantly. These results are in agreement with Nassar et al. (2011) on Kidney bean, Dawood et al. (2013) on Soybean, Nofal et al. (2016) on calendula plant, Abdallah et al. (2016) on quinoa plants and Dawood et al. (2019) on flax plant, concluding that yeast extract enhanced yield characters could be due to fact that yeast extract contain different macro- and micronutrients, auxin and cytokinins, it is also rich with vitamins especially B which stimulate plant growth and yield characters (MirabalAlonso et al., 2008 and Dawood et al., 2019). On the other hand, Abdel-Hakim et al. (2012) on Snap Bean, and Youssef et al. (2017) on sunflower, found that yield characters were enhanced by foliar application with SA could be attributed to the fact that SA participates in different plant physiological processes as stomatal closure, protein synthesis, transpiration and photosynthesis (Khan et al., 2003). Salicylic acid also has a direct effect in alteration of antioxidant enzyme activities, and nutrient uptake (Alvarez, 2000 and Khandaker et al., 2011). 
Table 2: Effect of yeast extract and salicylic acid on yield characteristics of sunflower plant at 120 days after sowing in 2017 and 2018.

\begin{tabular}{|c|c|c|c|c|}
\hline \multirow[t]{3}{*}{ Treatments } & \multicolumn{3}{|c|}{ Yield characters } & \multirow[b]{3}{*}{$\begin{array}{c}100 \text { seed weight } \\
\text { (g) }\end{array}$} \\
\hline & \multicolumn{3}{|c|}{$\mathbf{1}^{\text {st }}$ Season } & \\
\hline & $\begin{array}{c}\text { Head } \\
\text { Diameter } \\
(\mathrm{cm}) \\
\end{array}$ & $\begin{array}{l}\text { No. of seeds } \\
\text { /capitulum }\end{array}$ & $\begin{array}{c}\text { seed } \\
\text { yield/ } \\
\text { plant (g) }\end{array}$ & \\
\hline Control & 16.47 & 853.50 & 45.30 & 6.80 \\
\hline Yeast extract $2 \mathrm{~g} / \mathrm{L}$ & 16.74 & 937.12 & 49.38 & 7.42 \\
\hline Yeast extract 4g/L & 21.02 & 1132.84 & 58.86 & 8.90 \\
\hline Yeast extract 8g/L & 19.54 & 990.32 & 52.27 & 7.60 \\
\hline Yeast extract $12 \mathrm{~g} / \mathrm{L}$ & 14.81 & 819.39 & 42.59 & 6.42 \\
\hline Salicylic acid $50 \mathrm{mg} \mathrm{L}^{-1}$ & 17.82 & 935.72 & 49.41 & 7.23 \\
\hline Salicylic acid $100 \mathrm{mg} \mathrm{L}^{-1}$ & 20.30 & 1104.22 & 56.43 & 8.31 \\
\hline Salicylic acid $150 \mathrm{mg} \mathrm{L}^{-1}$ & 18.56 & 974.49 & 50.58 & 7.67 \\
\hline Salicylic acid $300 \mathrm{mg} \mathrm{L}^{-1}$ & 14.50 & 775.26 & 42.03 & 6.17 \\
\hline \multirow[t]{3}{*}{ L.S.D(0.05) } & 2.05 & 86.37 & 4.17 & 0.65 \\
\hline & \multicolumn{2}{|c|}{$2^{\text {nd }}$ Season } & & \\
\hline & $\begin{array}{c}\text { Disk } \\
\text { Diameter } \\
(\mathbf{c m})\end{array}$ & $\begin{array}{l}\text { No. of seeds } \\
\text { /capitulum }\end{array}$ & $\begin{array}{c}\text { seed } \\
\text { yield/plant } \\
\text { (g) } \\
\end{array}$ & $\begin{array}{c}100 \text { seed weight } \\
\text { (g) }\end{array}$ \\
\hline Control & 16.79 & 835.81 & 44.65 & 6.65 \\
\hline Yeast extract $2 \mathrm{~g} / \mathrm{L}$ & 17.58 & 908.94 & 47.27 & 7.27 \\
\hline Yeast extract 4g/L & 20.85 & 1078.37 & 55.62 & 8.36 \\
\hline Yeast extract 8g/L & 19.57 & 959.58 & 51.54 & 7.53 \\
\hline Yeast extract $12 \mathrm{~g} / \mathrm{L}$ & 14.25 & 760.26 & 41.60 & 5.98 \\
\hline Salicylic acid $50 \mathrm{mg} \mathrm{L}^{-1}$ & 17.02 & 907.84 & 47.18 & 7.23 \\
\hline Salicylic acid $100 \mathrm{mg} \mathrm{L}^{-1}$ & 20.23 & 1029.90 & 53.05 & 8.20 \\
\hline Salicylic acid $150 \mathrm{mg} \mathrm{L}^{-1}$ & 18.88 & 928.04 & 49.70 & 7.39 \\
\hline Salicylic acid $300 \mathrm{mg} \mathrm{L}^{-1}$ & 13.24 & 757.88 & 40.74 & 5.92 \\
\hline L.S.D(0.05) & 2.08 & 74.90 & 2.78 & 0.64 \\
\hline
\end{tabular}

\section{Anatomical studies}

The microscopical measurements of the transverse sections through the median portion of the main stem of untreated plants and those treated with yeast extract $4 \mathrm{~g} / \mathrm{L}$ and SA $100 \mathrm{mg} \mathrm{L}^{-1}$ are presented in Table (3) and Fig. (1).

Table 3: Measurements in microns $(\mu)$ of anatomical characters in transverse sections through the median portion of the main stem of Sunflower plant grown in the $2^{\text {nd }}$ season of 2018 treated with foliar application of yeast extract and SA.

\begin{tabular}{lccc}
\hline & \multicolumn{2}{c}{ Treatments } \\
\hline Characters & Control & Yeast extract 4g/L & Salicylic acid 100 $\mathbf{~ m g ~ L}^{-\mathbf{1}}$ \\
\hline Stem diameter & 12200 & 15630 & 14250 \\
Epidermis thick. & 30 & 30 & 30 \\
Cortex thick. & 600 & 451 & 427.5 \\
Fiber cap thick. & 230 & 320 & 310 \\
Phloem thick. & 268.7 & 335 & 330 \\
Xylem thick. & 852.5 & 1242.5 & 1140.5 \\
Vessel diameter & 100 & 145.1 & 131.6 \\
No. of xylem rows / bundle & 7.0 & 9.0 & 8.4 \\
Pith diameter & 8300 & 10645 & 9565 \\
\hline
\end{tabular}




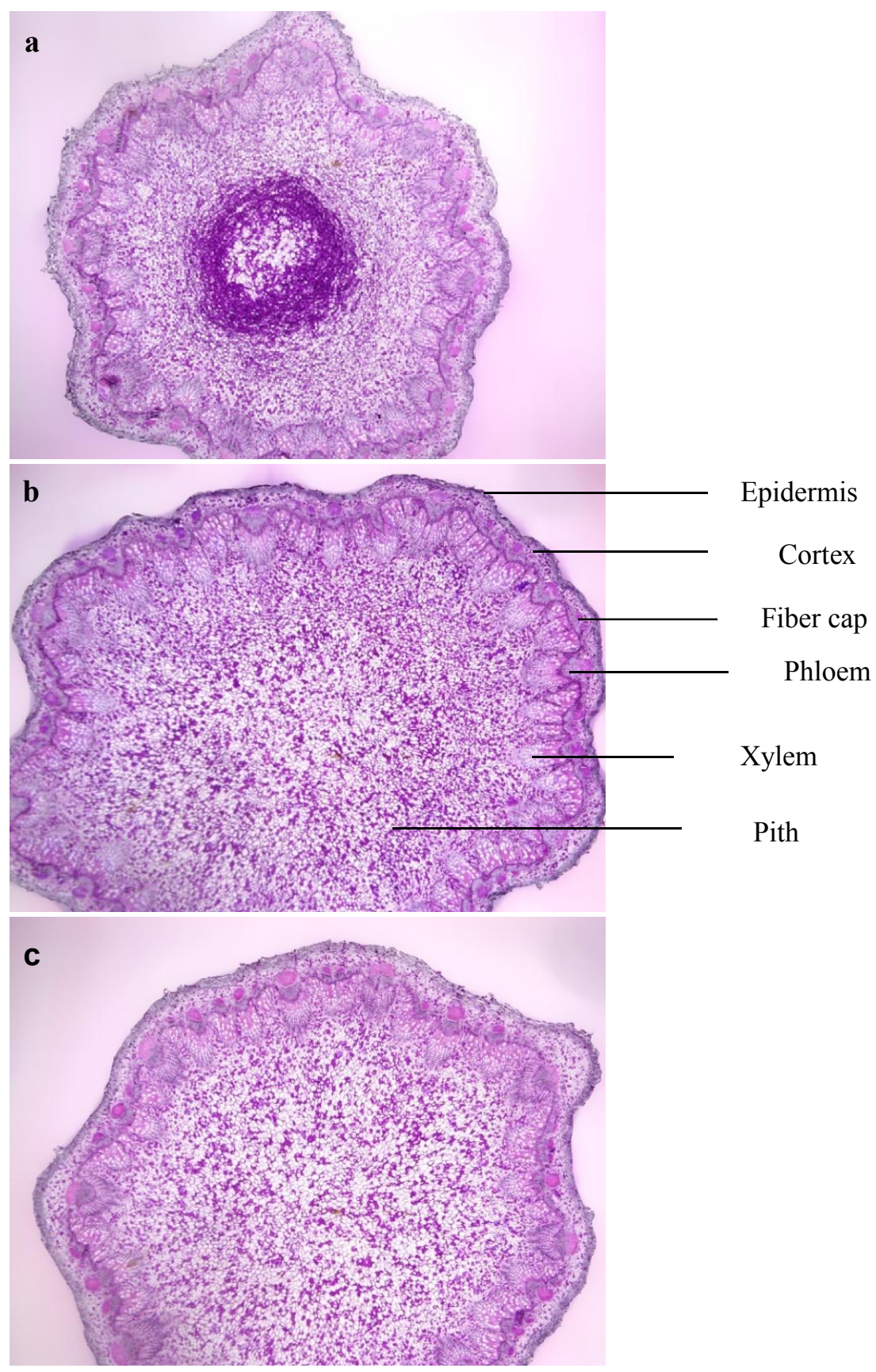

Fig. 1: Transverse sections through median portion of the main stem of Sunflower cv. 'Sakha-53' at the age of 75 days sprayed with yeast extract and salicylic acid. (X 20)
a- Untreated plant (control).
b- Plant sprayed with $4 \mathrm{~g} / \mathrm{L}$ yeast extract.
c- Plant sprayed with $100 \mathrm{mg} \mathrm{L}^{-1} \mathrm{SA}$.

Regarding the effect of yeast extract, it is clear that, yeast extract treatment caused a prominent increase in stem diameter reached $28.1 \%$ more than the control plants. This increment reflects the increase occurred in all internal tissues, i.e., fiber cap, phloem, xylem, vessel diameter and pith diameter with values of $39.1,24.6,45.7,45.1$, and $28.2 \%$ more than the control, respectively. On the other hand, plants sprayed with SA at $100 \mathrm{mg} \mathrm{L}^{-1}$ gave wider stem diameter than the control plants by $16.8 \%$. This increment could be attributed mainly to the prominent increase in fiber cap by $34.7 \%$, 
phloem tissue by $22.8 \%$, xylem tissue by $33.7 \%$, vessel diameter by $31.6 \%$ and pith diameter by $15.2 \%$ more than those of the control plants. Cortex thickness was decreased in both yeast extract and SA treatments by 27.8 and $28.8 \%$, respectively. The effect of yeast extract as well as SA are previously studied by Nassar et al. (2011) on Kidney Bean, they reported that foliar application of yeast extract at $100 \mathrm{ml} / \mathrm{L}$ increased plant stem diameter, cortex, phloem tissue, xylem tissue and parenchymatous area of the pith. Azoz (2014) stated that yeast extract enhanced the anatomical characters of Basil plants. Gomaa et al. (2015) found that foliar spray with $75 \mathrm{ppm}$ SA induced prominent increase in stem diameter of Egyptian Lupine plant. Seleem (2016) who found that foliar application of yeast extract $4 \mathrm{~g} / \mathrm{L}$ or SA $200 \mathrm{ppm}$ enhanced the anatomical structure of Calendula plant.

\section{Fatty acid analysis}

Foliar application by yeast extract as well as SA had positive effect on the fatty acids. Increasing yeast extract concentration from 2 to 8 , and SA concentration from 50 to $150 \mathrm{mg} \mathrm{L}^{-1}$ caused a reduction in the content of the saturated fatty acids. The lowest percentages of lauric, palmitic and stearic acids were observed at the $4 \mathrm{~g} / \mathrm{L}$ yeast concentration and $100 \mathrm{mg} \mathrm{L}^{-1} \mathrm{SA}$ concentration, while the highest concentration of yeast $12 \mathrm{~g} / \mathrm{L}$ and $300 \mathrm{mg} \mathrm{L}^{-1} \mathrm{SA}$ led to slightly increase of the previous fatty acids. On the other hand, the first three concentrations of yeast extract, and SA increased the oil content of oleic, linoleic and linolenic acids. The most effective concentration of yeast and SA were $4 \mathrm{~g} / \mathrm{L}$ and $100 \mathrm{mg} \mathrm{L}^{-1}$, respectively, which reach the previous unsaturated fatty acids to the maximum (Table 4). The previous results are in agreement with the finding of Noreen et al. (2009) on sunflower, who stated that application of SA significantly increased seed oil content and essential unsaturated fatty acids, but it decreased stearic acid.

Ullah and Bano (2011) found that SA increased oleic acid and linoleic acid contents of safflower plants. Jadhav et al. (2013) on Groundnut seeds stated that application of SA at $50 \mathrm{ppm}$ lowered the palmitic and stearic acid contents, and enhanced oleic acid contents, and $100 \mathrm{ppm}$ SA increased linoleic acid contents. Basiri et al. (2017) on sunflower plant seeds, which found that SA spraying plants with of $0.2 \mathrm{~g} \mathrm{~L}^{-1} \mathrm{SA}$ increased content of oil and unsaturated fatty acids but decreased the amount of saturated fatty acids.

Table 4: Effects of yeast extract and salicylic acid on fatty acids content (\%) of sunflower seed oil at 120 days from sowing date

\begin{tabular}{|c|c|c|c|c|c|c|c|c|c|}
\hline $\begin{array}{l}\text { Fatty Acids } \\
\text { Name }\end{array}$ & Control & $\begin{array}{c}\text { Yeast } \\
\text { extract } \\
2 \mathrm{~g} / \mathrm{L}\end{array}$ & $\begin{array}{c}\text { Yeast } \\
\text { extract } \\
4 \mathrm{~g} / \mathrm{L}\end{array}$ & $\begin{array}{c}\text { Yeast } \\
\text { extract } \\
8 \mathrm{~g} / \mathrm{L}\end{array}$ & $\begin{array}{c}\text { Yeast } \\
\text { extract } \\
12 \mathrm{~g} / \mathrm{L}\end{array}$ & $\begin{array}{l}\text { SA } 50 \\
\text { mg L- } \\
1\end{array}$ & $\begin{array}{l}\text { SA } 100 \\
\text { mg } L^{-1}\end{array}$ & $\begin{array}{l}\text { SA } 150 \\
\text { mg L L }^{-1}\end{array}$ & $\begin{array}{c}\text { SA } \\
300 \mathrm{mg} \\
\mathrm{L}^{-1}\end{array}$ \\
\hline Lauric & 2.82 & 2.65 & 1.08 & 1.15 & 2.86 & 2.34 & 1.12 & 1.77 & 3.18 \\
\hline Palmitic & 2.73 & 2.31 & 1.02 & 1.53 & 3.02 & 2.14 & 1.08 & 1.72 & 3.11 \\
\hline Stearic & 4.47 & 3.55 & 1.50 & 1.74 & 3.76 & 3.71 & 1.85 & 2.11 & 4.24 \\
\hline Oleic & 25.19 & 25.92 & 37.53 & 30.33 & 20.99 & 26.45 & 30.35 & 28.18 & 23.66 \\
\hline Linoleic & 43.74 & 48.71 & 52.65 & 48.84 & 40.06 & 45.13 & 50.56 & 46.04 & 43.75 \\
\hline Linolenic & 1.00 & 1.67 & 2.13 & 1.64 & 1.42 & 1.13 & 1.96 & 1.67 & 1.26 \\
\hline
\end{tabular}

\section{Conclusion}

Results of this experiment showed that, application of yeast extract at $2 \mathrm{~g} / \mathrm{L}$ up to $8 \mathrm{~g} / \mathrm{L}$ concentrations enhanced morphological, anatomical and yield characters, as well as the percentage of unsaturated fatty acids and decreased the saturated fatty acid. While the highest concentration of yeast extract $12 \mathrm{~g} / \mathrm{L}$ decreased the previous studied characters. Likewise, salicylic acid foliar spraying had the same effect as yeast extract. The best concentrations were $4 \mathrm{~g} / \mathrm{L}$ yeast extract, and $100 \mathrm{mg} \mathrm{L}^{-1} \mathrm{SA}$ which increased significantly all the studied characters and improved the oil quality by increasing the unsaturated fatty acids. 


\section{References}

Abdallah, M. M. S., S. F. El Habbasha and T. El Sebai, 2016. Comparison of yeast extract and Nicotinaminde foliar applications effect on quinoa plants grown under sandy soil condition. International Journal of PharmTech Research, 9(7): 24-32.

Abdel-Hakim, W. M., Y.M.M. Moustafa, and R.H.M. Gheeth, 2012. Foliar Application of Some Chemical Treatments and Planting Date Affecting Snap Bean (Phaseolus vulgaris L.) Plants Grown in Egypt. Journal of Horticultural Science \& Ornamental Plants, 4 (3): 307-317.

Abdul Qados, Amira M. S., 2015. Effects of Salicylic Acid on Growth, Yield and Chemical Contents of Pepper (Capsicum annuum L.) Plants Grown Under Salt Stress Conditions. International Journal of Agriculture and Crop Sciences, 8 (2): 107-113.

Abou EL-Yazied, A. and M. A. Mady, 2012. Effect of Boron and Yeast Extract Foliar Application on Growth, Pod Setting and both Green Pod and Seed Yield of Broad Bean (Vicia faba L.). Journal of American Science, 8(4): 517-533.

Alvarez M.E., 2000. Salicylic acid in the machinery of hypersensitive cell death and disease resistance. Plant Molecular Biology, 44: 429-442.

Amer, S.S.A., 2004. Growth, green pods yield and seeds yield of common bean (Phaseolus vulgaris L.) as affected by active dry yeast, salicylic acid and their interaction. Journal of Agricultural Science Mansoura University, 29(3): 1407-1422.

A.O.A.C., 2000. Official Methods of Analysis of the Association of Official Analytical Chimist. $14^{\text {th }}$ cd Washington, D.C.

Azoz, S.N., 2014. Botanical studies on Basil plant (Ocimum basilicum L.) and its response to foliar application with yeast extract. Ph.D. Thesis. Cairo Univ., Egypt, 206p.

Basiri, Hajar, K., M. Sedghi, and R.S. Sharifi, 2017. Effect of salicylic acid on the quality of edible oil and fatty acids composition in different regions of sunflower (Helianthus annuus L.) heads. Iranian Journal of Plant Physiology, 8 (1): 2285-2292.

Dawood, M. G., S.R. El-Lethy and Sadak, M. Sh., 2013. Role of methanol and yeast in improving growth, yield, nutritive value and antioxidants of Soybean. World Applied Science Journal, 26 (1): 06-14.

Dawood, Mona G., Sadak, Mervat Sh., Abdallah, Maha, M.Sh., B.A. Bakry and O.M. Darwish, 2019. Influence of biofertilizers on growth and some biochemical aspects of flax cultivars grown under sandy soil conditions. Bulletin of the National Research Centre, 43:81.

El Mantawy, Rania F., 2017. Physiological Role of Antioxidants in Improving Growth and Productivity of Sunflower under Different Sources of Nitrogen Fertilizers. Egyptian Journal of Agronomy, 39 (2):167- 177.

El-Desuki, M. and El-Gereadly, Nadia H.M., 2006. Response of Pea Plants to foliar application of yeast extract. Journal of Agricultural Science Mansoura University, 31 (10): 6667-6674.

El-Tohamy, W. A., H. M. El-Abagy, and N. H. M. El- Greadly, 2008. Studies on the effect of putrescine, yeast and vitamin $\mathrm{C}$ on growth, yield and physiological responses of eggplant (Solanum melongena L.) under sandy soil conditions. Australian Journal of Basic and Applied Sciences, 2 (2): 296-300.

FAOSTAT, 2019. http://www.fao.org/faostat/en/\#data/QC.

Farag, R.S., S.A.S. Hallabo, F.M. Hewdi, and A.E. Basyony, 1986. Chemical Evaluation of Rape seed. Fette-Seifen Anstrichmittel., 88(10): 391-397.

Fariduddin, Q., S. Hayat, and A. Ahmad, 2003. Salicylic acid influences net photosynthetic rate, carboxylation efficiency, nitrate reductase activity and seed yield in Brassica juncea. Photosynthetica, 41: 281-284.

FAS-USDA, 2017. Foreign Agricultural Service/ United States Department of Agricultural.

Gomaa, Elham F., Nassar, Rania M.A. and M.A. Madkour, 2015. Effect of Foliar Spray with Salicylic Acid on Vegetative Growth, Stem and Leaf Anatomy, Photosynthetic Pigments and Productivity of Egyptian Lupine Plant (Lupinus termis Forssk.), International Journal of Advanced Research, 3(1): 803-813. 
Hamed, S.F., S. M. Wagdy and M.G. Megahed, 2012. Chemical characteristics and antioxidant capacity of Egyptian and Chinese sunflower seeds: A case study. Life Science Journal, 9(2):320328.

Hamza, M. and S.A. Safina, 2015. Performance of sunflower cultivated in sandy soils at a wide range of planting dates in Egypt., Journal of plant production Mansoura University, 6 (6):821-835.

Hasanuzzaman, M., K. Nahar, M.M. Alam, S. Ahmad and M. Fujita, 2015. Exogenous application of phytoprotectants in legumes against environmental stress. Legumes under Environmental Stress: Yield, Improvement and Adaptations, pp.161-197.

Hayat, Q., S. Hayat, M.N. Alyemeni, and A. Ahmad, 2010. Salicylic acid mediated changes in growth, photosynthesis, nitrogen metabolism and antioxidant defense system in Cicer arietinum L. Plant, Soil and Environment, 58 (9): 417-423.

Jadhav S.H., S.B. Bhambudekar and D.B. Patil, 2013. Effect of salicylic acid on fatty acid composition of groundnut seeds. National Conference of plant physiology on 'Current Trend in Plant Biology Reasearch, 740-741 pp.

Jayakannan, M., J. Bose, O. Babourina, Z. Rengel and S. Shabala, 2013. Salicylic acid improves salinity tolerance in Arabidopsis by restoring membrane potential and preventing salt-induced $\mathrm{K}+$ loss via a GORK channel. Journal of Experimental Botany. 64(8):2255-2268.

Khan W., P. Balakrishnan and D.L. Smith, 2003. Photosynthetic responses of corn and soybean to foliar application of salicylates. Journal of Plant Physiology, 160 (5): 485-492.

Khandaker, Laila, Masum Akond, A.S.M.G., and Oba, Sh., 2011. Foliar application of salicylic acid improved the growth, yield and leaf's bioactive compounds in red amaranth (Amaranthus tricolor L.). Vegetable Crops Research Bulletin, 74: 77-86.

Konyal1, S., 2017. Sunflower Production, Consumption, Foreign Trade and Agricultural Policies in Turkey, Social Sciences Research Journal, 6 (4): 11-19.

Mirabal-Alonso, L., D. Kleiner and E. Ortega, 2008. Spores of the mycorrhizal fungus Glomus mosseae host yeasts that solubilize phosphate and accumulate polyphosphates. Mycorrhiza, 18: 197-204.

Nassar, M.A. and K.F. El-Sahhar, 1998. Botanical Preparations and Micriscopy (Microtechnique). Academic Bookshop, Dokki, Egypt, 219 p. (In Arabic).

Nassar, Rania M.A., Y.M. Ahmed, and Nassar, Dalia M. A., 2011. Effect of Foliar Spray with Active Yeast Extract on Morphological, Anatomical and Yield Characteristics of Kidney Bean (Phaseolus vulgaris L.). Australian Journal of Basic and Applied Sciences, 5(5): 1071-1079.

Nofal, Fayza H., M.U. El-Segai, and Seleem, Engy A., 2016. Influence of yeast natural extract on growth, flowering, yield and some anatomical structure of marigold (Calendula officinalis L.) plant. Journal of Plant Production, Mansoura University, 7(2): 177 - 183.

Noreen, S. and M. Ashraf, 2008. Alleviation of adverse effects of salt stress on sunflower (Helianthus annuus L.) by ex-ogenous application of salicylic acid: growth and photosynthesis. Pakistan Journal of Botany, 40(4): 1657-1663.

Noreen, S., M. Ashraf, M. Hussain and A. Jamil, 2009. Exogenous application of salicylic acid enhances antioxidative capacity in salt stressed sunflower (Helianthus annuus L.) plants. Pakistan Journal of Botany, 41(1): 473-479.

Noreen, S., A. Siddiq, K. Hussain, S. Ahmad, and M. Hasanuzzaman, 2017. Foliar application of salicylic acid with salinity stress on physiological and biochemical attributes of sunflower (Helianthus annuus L.) crop. Acta Scientiarum Polonorum-Hortorum Cultus, 16(2), 57-74.

Orabi, Salwa A., B.B. Mekki, , and Sharara, Faida A., 2013. Alleviation of Adverse Effects of Salt Stress on Faba Bean (Vicia faba L.) Plants by Exogenous Application of Salicylic Acid. World Applied Sciences Journal, 27 (4): 418-427.

Seleem, Engy, A., 2016. Enhancement the Characters of Calendula Plant Grown under Saline and Non saline Conditions by Using Growth Stimulants. Ph.D. Thesis. Cairo Univ., Egypt, 179p.

Marzauk, N.M., M.R. Shafeek, Y.I. Helmy, A.A. Ahmed, A.F. Magda, and M.F. Shalaby, 2014. Effect of vitamin $\mathrm{E}$ and yeast extract foliar application on growth, pod yield and both green pod and seed yield of broad bean (Vicia faba) L. Middle East Journal of Applied Sciences, 4(1): 6167. 
Shaki, F., H.E. Maboud, and V. Niknam, 2019. Effects of salicylic acid on hormonal cross talk, fatty acids profile, and ions homeostasis from salt stressed safflower. Journal of Plant Interactions, 14 (1): 340-346.

Shalaby, T.A. and H. El-Ramady, 2014. Effect of foliar application of bio-stimulants on growth, yield, components, and storability of garlic (Allium sativum L.). Australian Journal of Crop Science, 8(2):271-275.

Soltani, Y., V.R. Saffari and A. A. Maghsoudi Moud, 2014. Response of growth, flowering and some biochemical constituents of Calendula officinalis L. to foliar application of salicylic acid, ascorbic acid and thiamine. Ethno-Pharmaceutical Products, 1(1): 37-44.

Ullah, F. and A. Bano, 2011. Effect of plant growth regulators on oil yield and biodiesel production of safflower (Carthamus tinctorius L.). Brazilian Society Journal of Plant Physiology, 23(1): 27-31.

USDA, 2008. Accessed on, 2009/07/25, http:// www.nal. usda. gov/ fnic/food comp/ cgibin/ list nut edit.pl.

Vogel, A. J., 1975. A text book of practical organic chemistry. $3^{\text {rd }}$ ed. P. 969-971, English Language Book Society and Longman Group Ltd. London.

Wanas, A. L., 2006. Trails for improving growth and productivity of tomato plants grown in winter. Annals of Agricultural Science Moshtohor, 44(3): 466-471.

Youssef, R.A., El-Azab, Mona E., Mahdy, Hayam A.A., Essa, Entsar M., Kassem A.S. and K.A.S. Mohammed, 2017. Effect of Salicylic acid on growth, yield, nutritional status and physiological properties of Sunflower plant under salinity stress, International Journal of Pharmaceutical and Phytopharmacological Research, 7 (5): 54-58. 